\title{
Digitalisation and the church - A corporeal understanding of church and the influence of technology
}

\author{
Potgieter, Annette \\ University of Pretoria, Pretoria, South Africa \\ annettepotgieter1@gmail.com
}

\begin{abstract}
We live in a digital era, where connection and connectivity move away from physical presence, but find shape in online communities and forums. This trend extends from the secular world into the religious experience, as can be seen from examples such as E-kerk (E-Church). The body is a vehicle through which Paul defines the church and the medium through which Christians live a new life in Christ. Virtual communities, however, lack bodily presence and thus the tactile experience of the Lord's Supper and the communal aspects of baptism. This raises the question whether it is possible for an individual to participate online in the body of Christ and if so, how?
\end{abstract}

Key words

Baptism; digital church; community; online ethic

\section{Introduction}

In a digital era, connection and connectivity move more away from physical presence and finds shape in online communities and forums. At the touch of a mere button, or the click of a finger, an instant connection is obtainable. Communities such as Facebook, MySpace, Instagram and Twitter foster digital friendships and relationships. ${ }^{1}$ The Internet has impacted our society by empowering an individual to post and comment without inhibition. Any person may have an opinion, an opinion that is readily posted and shared, without any sense of responsibility. These

1 Todd J. Mullins, “Online Church: A Biblical community” (PhD diss. Liberal Theological Seminary, 2011), 6 . 
opinions exist virtually without the possibility of ever being truly deleted. Words matter and in a virtual world, words can be immortal.

The digital era pervades our society to the extent that it does not determine our society but becomes our society according to Peter Nagy and Bernadett Koles. ${ }^{2}$ Academia has not circumvented this phenomenon as is evident with the rise of the new academic field of "digital humanities." Unsurprisingly, rapid digitalisation also influences the church. Thereby creating an opportunity, but also the need for ethical parameters and the establishment of new definitions.

As a New Testament scholar currently working as a pastor in a mine industry community church in Rustenburg, the effects of the digital era are also pervasive. Our congregation, following the trend of most mainline congregations, streams our services via Skype and Sound Cloud. Congregants, who work in foreign countries due to the struggling mining industry, particularly use the Skype option. This improves their sense of connection with their families who remain in Rustenburg, in the congregation. Sound Cloud is easily accessible via an online link from Facebook and is especially used by congregants who are not able to attend a service due to a lack of mobility, or who are struggling with their health, or even at times members of the congregation who are out of town. These channels provide a means for congregants to experience that they are still part of the church community. These channels, however, are only one-way communication, as the online participants are not heard or seen by the rest of the congregation and therefore are easily forgotten.

However, to be able to refer to a community as "church," obliges an understanding of the nature, calling and identity of the church. ${ }^{3}$ From a Pauline perspective, church is comprehended as the body of Christ (e.g. 1 Cor 10:17, 11:29). ${ }^{4}$ The terminology is also used in Eucharistic contexts

2 Peter Nagy \& Bernadett Koles “The digital transformation of human identity: Towards a conceptual model of virtual identity in virtual worlds" The International Journal of Research into New Media Technologies 20, no. 3 (2014): 277.

3 Wim Dreyer, “The real crisis of the church”, HTS Theological Studies 71, no. 3 (2015), Art. \#2822, 5.

4 Ronald Y. K. Fung, "Body of Christ," in Dictionary of Paul and his letters, eds. G.F. Hawthorne, R.P. Martin \& D.G. Reid (Downers Grove, Illinois: IVP, 1993), 76-77. 
referring to participation in the blood and the body of Christ (e.g. 1 Cor

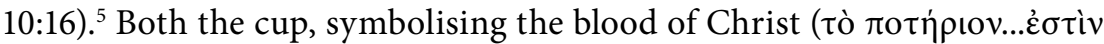

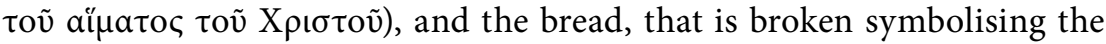

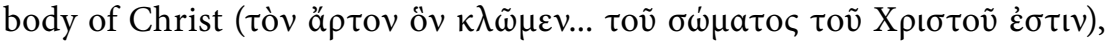

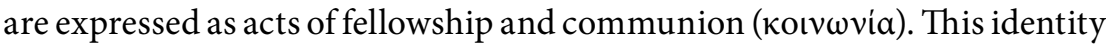
is expressed as communio. A phenomenon that communicates being incorporated into Christ, manifested in the belonging and the fellowship that shapes church as a visible unity united with Christ. ${ }^{6}$ This unity with Christ is immanent during the material participation of sacraments. ${ }^{7}$

Accordingly, is it possible to think of a digital body of Christ? Of even greater significance is the question - how is understanding the church as the body of Christ compatible with a virtual world? Is there such a thing a digital church? Furthermore, this raises the question as to what type of online presence does the church want to advocate?

The assumption of this article is that church and community should be interpreted from a corporeal perspective. Accordingly, this article will investigate what is intended with church and community from a Pauline perspective, specifically drawing on Romans 6:1-14. Arguing from a corporeal approach, the article examines the connection between church and a growing online presence, especially investigating what this entails for the church's perceived identity in Christ. What role the church may play will be discerned.

\section{A corporeal perspective: Rom 6:1-14}

Although online communities facilitate communication, they can only function in a supportive manner, I'd like to argue on account that it lacks the opportunity for participating in the baptism as well as the Eucharist. It is necessary to move online participants away from their screens, to physically attend a place of worship at times.

5 Ibid, 76-77.

6 Dirkie J. Smit "Calvin on the sacraments and church unity". In die Skriflig 44, no. 3 (2010): 255.

7 Ibid, 258. 
Paul's emphasis on the participation in the body of Christ is evident in Romans 6:1-14. In the pericope of Romans 6:1-14, the preposition $\sigma \dot{v} v$ is repeated (cf. 6:4; 5; 6; 8;), accentuating the notion of "with." Throughout the pericope, it becomes clear that Paul envisions only two types of people, dead people, or people who truly live. Dead people are people who remain in sin. People who truly live are people who are under the lordship of Christ.

Physical participation becomes intertwined with being either dead or alive, as Paul uses the baptism as a metaphor in Rom 6:3 to illustrate the importance of believers' participation in the death and resurrection

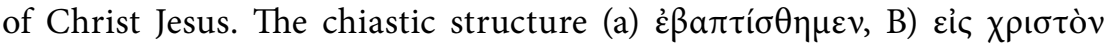

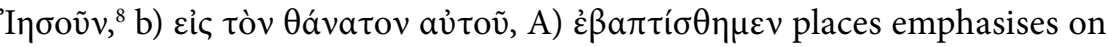
the verb $\beta a \pi \tau i \zeta \omega$. With the repetition Paul creates a connection between

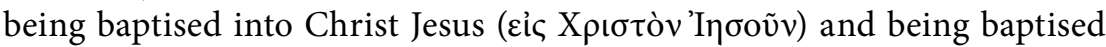

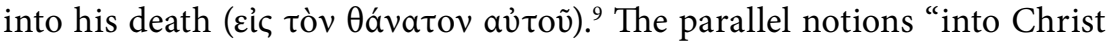

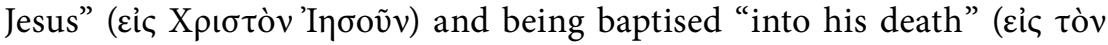

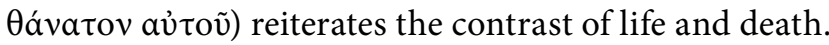

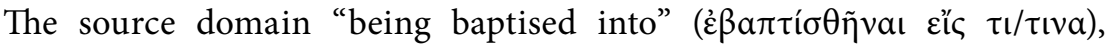
involves being dipped into something. ${ }^{10}$ The preposition eis is typically used with $\beta a \pi \tau i \zeta \omega$ "to dip into," ${ }^{11}$ but spatiality is also implied. ${ }^{12}$ The phrase

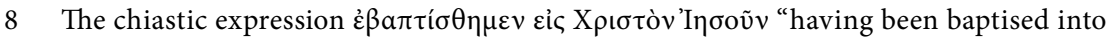
Christ Jesus" can also be found in Galatians 3:27 and 1 Corinthians 10:2.

9 In Mark 10:38-39 as well as Luke 12:50, Jesus refers to his death as his "baptism" thereby connecting the idea of baptism and death. Cf. Richard Longenecker, Romans (Grand Rapids: Eerdmans, 2016), 613.

10 The verb $\beta a \pi \tau i \zeta \omega$ literally means, "to plunge." Polybius employs the verb with regards to a "sinking" ship. See Polyb. I, LI.7. L. Morris, The Epistle to the Romans (Grand Rapids: William B. Eerdmans Publishing Company, 1988), 246 especially notes the meanings of drowning and sinking points to associations of violence. Josephus used $\beta a \pi \tau i \zeta \omega$ metaphorically to refer to crowds who flooded into Jerusalem and "wrecked the city" in Bell. 4.137. Moreover, baptism has already acquired a specific meaning in early Christian communities.

11 Cf. BDAG, 291. Paul's use of the preposition with baptism is labelled by Arland J. Hultgren, Romans, (Grand Rapids: Eerdmans, 2011), 245 according to L. Hartman, 'into the name of the Lord Jesus", as "both un-biblical and un-Greek" as it does not appear in LXX and in secular Greek. Contra H. Schlier, Der Römerbrief, (Freiburg: Herder, 1977), 192 the formula is used in the Hellenistic law and administration language.

12 Cf. Cilliers Breytenbach, "Taufe als räumliche Metapher in den Briefen des Paulus" in Spatial Metaphors. Ancient Texts and Transformations, eds. C. Breytenbach \& F. Horn. Berlin Studies of Ancient World 39, 2016), 281; Douglas J. Moo, Romans (Grand 


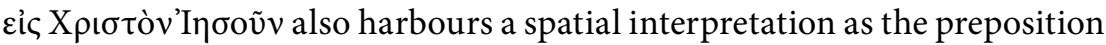
$\varepsilon i \zeta$ is used in a locative manner. Paul is not interested in defining baptism, ${ }^{13}$ but rather his use of this metaphor indicates two assumptions. Firstly, believers were baptised and thus familiar with the image ${ }^{14}$ and secondly, baptism during Paul's lifetime was always associated with being converted. Accordingly, the image differentiates strongly between believers' status prior to Christ and after Christ. ${ }^{15}$ Paul coherently employs the distinction between the audience's past situation and present situation throughout the argument of Romans 5-8, of which Romans 6:1-14 forms part of.

Paul clearly links Christ Jesus with his death reminiscent of the cross event. That X with the resurrection, ${ }^{16}$ becomes explicit correspondingly in the ensuing verse. Believers are baptised into Christ Jesus and are baptised into his death. Just as Christ was resurrected by the glory of the Father, the baptised may walk in the newness of life drawing on the glory and life that God

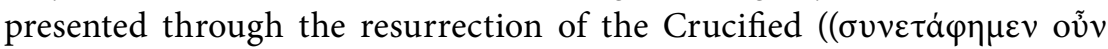

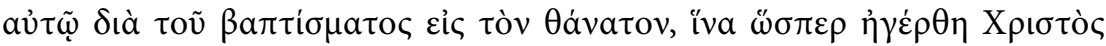

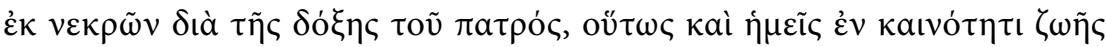
$\pi \varepsilon \rho \iota \pi \alpha \eta \dot{\sigma} \sigma \mu \varepsilon v) 6: 4)$. It is not physically possible to be "in Jesus Christ,"

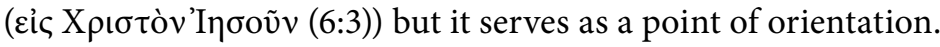

Accordingly, believers orientate themselves into this present state of Christ' victory over death, which inherently implies to be able to live. If a believer is orientated "in" they have access to life, but "out" becomes synonymous with death. Accordingly, being in Christ is perceived as a state of affairs

Rapids: Eerdmans, 1996), 359-360; Michael Wolter, Römer (Göttingen: Neukirchener Theologie Patmos Verlag, 2014), 371.

13 Paul's intention is not to provide a comprehensive definition of baptism. Cf. B.S.J. Byrne, Romans, (Collegeville Minnesota, The Liturgical Press, 1996), 189.

14 Cf. C.G. Kruse, Romans (Grand Rapids: Eerdmans, 2012), 258; Byrne, Romans, 189.

15 Cf. Wolter, Römer, 370. Baptism is used as a Christian sacrament of initiation after Jesus' death. Cf. BDAG, 164; LSJ, 305. There are many references in Jewish scripture to the purification of people through water, but baptism as an initiatory religious rite is foreign to these scriptures. Excavations of the southern end of the Temple Mount at Jerusalem and throughout Judea indicates that Jews of the first century C.E. constructed ritual baths for purifications purposes. There was even ritual baths at Qumran. Cf. Longenecker, Romans, 612-613.

16 Cf. 2 Cor 13:4. Cf. Dieter Zeller, Römer, (Regensburg: Verlag Friedrich Pustet Regensburg, 1985), 124. 
attained through baptism. ${ }^{17}$ The in-out orientation would entail that if you were not baptised, you would not be part of being in Christ. To be in Christ means to be partake in his death and thus to be separated from $\sin .{ }^{18} \mathrm{~A}$ believer could regress ${ }^{19}$ into a state of being dominated by sin as the result

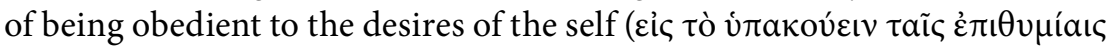
aủंoṽ (Rom 6:12b)). ${ }^{20}$ Paul urges believers to present themselves to God

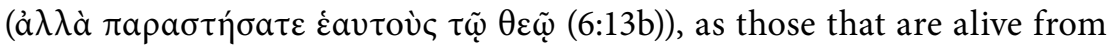

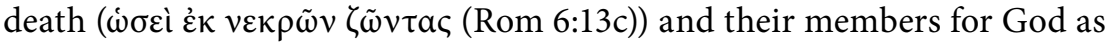

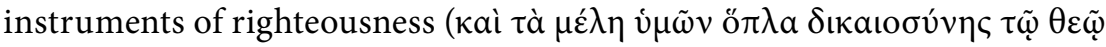
(Rom 6:13d)).

Accordingly, in order for a believer to truly be alive and to live out his/ her faith, it is necessary to continually present yourself to God. Presenting yourself is inherently bodily and requires purposeful orientation towards Christ. For Paul, a life without Christ is not possible. Breathing whilst not being under the lordship of Christ equates to death. A person is only truly alive when under the lordship of Christ. What is more, the lordship of Christ also involves access to eternal life, on account that grace might reign through righteousness leading to eternal life through Jesus Christ

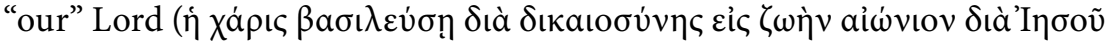

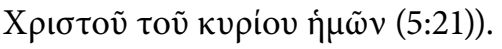

17 R. A. Harrisville, Romans (Minneapolis: Augsburg Publishing House, 1980), 89 remarks Paul's idea of incorporation into the body of Christ does not necessitate a Hellenistic awareness of the Stoic notion of the animate creation as single organism indwelt by Reason or Soul, but ample evidence suggest Judaism also conceived existence as corporate and thus for a Jew to be cut off from his community is a far worse fate than the cessation of biological functions.

18 Byrne, Romans, 190 notes that baptism does not simply involve being joined but also integration into the death, burial and risen life.

19 Believers are orientated in Jesus Christ they have died to sin and it no longer has the authority to enforce its demands. Cf. R.H Mounce, Romans (USA: Broadman \& Holman Publishers, 1995), 153; J.A. Fitzmyer, Romans, (New York: Doubleday, 1993), 446.

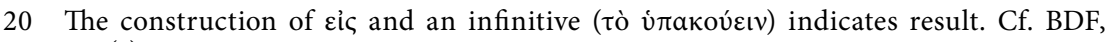
$\$ 337(1)$. 


\section{Digital church, space and community}

Churches streaming their services online have become a prevailing trend. Numerous churches in the USA, e.g. Saddleback, ${ }^{21}$ Calvary Chapel Fort Lauderdale ${ }^{22}$ and North Point Community church stream their services online supported by active Facebook communities. In Germany online churches are predominantly presented in English with a translator e.g. New Life Church Düsseldorf. ${ }^{23}$ The Evangelische Kirche Deutschland (EKD) is active in informing its members about church affairs via digitalisation with regards to the use of social media in German, but does not stream services. ${ }^{24}$ In the UK, online churches such as the Everyday Church online ${ }^{25}$, London Internet church ${ }^{26}$ and the Church of England ${ }^{27}$ utilise such channels. Churches predominantly use websites as advertisements and with the noble intention of getting their message across without truly understanding the impact of their online sites. Firstly, the digital age has brought on a shift in understanding what is information? ${ }^{28}$ And secondly, churches use of digital media illustrates an pre-digital understanding that the message can be controlled by the church. ${ }^{29}$ Information is no longer based on facts, but on feelings, just look at the American political scene or the manner in which the Brexit vote took place.

However, online services allow Christian believers and people who are curious about Christianity to have the luxury to experience aspects

21 “Saddleback," [Online]. Available: https://saddleback.com/watch [Accessed: 21 January 2019].

22 "Calvary Fort Lauderdale," [Online]. Available: https://www.calvaryftl.org/watch [Accessed: 21 January 2019].

23 "New life church," [Online]. Available: https://www.youtube.com/watch?v=Va5Pn_ VHy2U [Accessed: 19 January 2019].

24 "Kirche und digitalisierung," EKD. [Online]. Available: https://www.ekd.de/kircheund-digitalisierung-33392.htm [Accessed: 19 January 2019]

25 "Every day church.” [Online]. Available: http://everyday.org.uk/online [Accessed: 19 January, 2019]

26 "London internet church." [Online]. Available: http://londoninternetchurch.org.uk/ mobile/ [Accessed: 19 January 2019].

27 "Church of England." [Online]. Available: https://www.churchofengland.org/more/ media-centre [Accessed: 19 January 2019].

28 Claire Clivas, "New Testament in a Digital Culture: A Biblaridion (Little Book) Lost in the Web?" Journal of Religion, Media \& Digital Culture (JRMDC) 3, no. 3 (2014): 20.

29 See Clivas, "Digital Culture" 22. 
of church from the comfort of their own home. Procuring a website or streaming services is a necessary step for a church to take, as the intended audience has also been influenced by the digitalisation, e.g. high schools in Switzerland only uses iPads ${ }^{30}$ and in Rustenburg primary schools such as Protea Park uses iPads. The vast choices enable believers to participate where they want to, enjoying a church that always suits their needs, however, they are unable to participate and share their gifts with the community where they are needed. Consequently, churches could become culpable of creating a culture of church consumerism.

Of course, church ministry benefits from the possibility to create networks via the Internet. In a country such as South Africa, remote areas like the Northern Cape, or the Karoo in the Western Cape, which are vast, sparsely populated areas, online communities proffer a possibility to connect people in secluded areas. The E-kerk (E-Church), created by Stephan Joubert, serves as such a forum providing access to sermons, bible studies and information for general faith questions. ${ }^{31}$ The E-kerk (E-Church) is not established as a specific denomination but is only presented as church. There is also an online chat function inviting questions. Additionally, E-kerk (E-Church) also keeps its readers au courant with research and educational tools for pastors. A pastor, who is in a secluded area, without the possibility to participate in further training and learning opportunities, now has the opportunity to have access to the latest research. The Internet is not only beneficial for educational and communication purposes, but also aids in maintaining church structures. Skype conferencing calls provide a cheap solution for meetings, saving travel costs and connecting pastors from secluded places.

But what is more, technology has also provided the means to blur the boundaries between reality and fantasy with virtual identities. ${ }^{32}$ People can start online with a clean slate, unrestricted to their true reality and confinements, they have the possibility to choose their personalities and looks with avatars that resemble what they would like themselves to

30 See Clivas, "Digital Culture" 21.

31 "E-Kerk," Stephan Joubert [Online]. Available: http://www.ekerk.org [Accessed: 19 January 2019].

32 Nagy \& Koles, "Digital transformation," 279. 
resemble. ${ }^{33}$ One UK based online church has even gone a step further with an experimental virtual church, St. Pixels. Congregants in this community create an online avatar through which they can "pray" and "kneel" in a virtual church realm without ever having to physically meet. ${ }^{34}$ Identity can no longer be interpreted as a construct of the physical world in light of the digital era. ${ }^{35}$ Avatars create the possibility of a "third space. ${ }^{36}$ A realm that is considered to be neutral where people are comfortable to embody their "virtual self," an extension of their "real self." ${ }^{37}$ But how is having an avatar playing church not the epitome of individualism?

This brings up the crucial question of individualism versus collectivism. Body $(\sigma \tilde{\omega} \mu \alpha)$ in the ancient world describes a unified group of people, e.g. Cyr. Ins. 58, 'body of the Hellenes. ${ }^{38}$ For Paul, participation in the body of Christ is a crucial notion. ${ }^{39}$ The body plays a pivotal role in Paul's thought serving as an orientational point, providing the possibility to determine one's positioning towards God. This implies locality and space. ${ }^{40}$ This locality and space is not confined to a church building per se but does imply the physical presence of two or more people. ${ }^{41}$

Sacraments cannot function in isolation. A person cannot baptise him/ herself or partake in the Lord's Supper alone in front of a computer screen, as sacraments signify a bond of love. ${ }^{42}$ It is self-evident that with a virtual church participating in baptism or the Eucharist is not possible. Unless you would consider Eucharist to also entail organizing an online meeting at a specified time, with bread and wine in front of a computer via Skype. Much

33 Ibid. 279.

34 "Church of fools," [Online]. Available: www.stpixels.com [Accessed: 19 January 2019].

35 Cf. Nagy \& Koles, “Digital transformation,” 279.

36 Ibid., 280;

37 Ibid, 279.

38 BDAG, 984.

39 Jeremy Punt, "Paul, body theology: Parameters of discussion" Neotestamentica, 39, no. 2 (2005): 361.

40 Johannes N. Vorster, "Spaces vying for power: The rhetoric of religion as a rhetoric of spatiality and the role of the public intellectual” Religion \& Theology 17 (2010): 341.

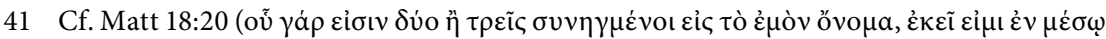

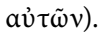

42 Cf. Smit "Sacraments and church," 260. 
like any other online meeting one attends. A group of practical theologians in Germany has tried such an approach to connect members in remote areas, but found the bread and wine never became true symbols of the body of Christ, they just remained a mere piece of bread and wine. ${ }^{43}$

The digital era has given a platform to humans' innate need for connectivity. However, although the Internet provides exciting new ways to connect, it has an indirect impact on the loneliness of people, through online socialising, with the negative impact, greater than the positive.$^{44}$ Exponents, such as Pam Smith ${ }^{45}$ argues online relationships can be just as meaningful as any other. Although it is possible, however, to Skype a loved one in a faraway country, it is not possible to hug them, to touch them and to experience their bodily presence. The opposite of the desired effect of connection is often created with Skype or Facebook. Often social media only increases a persons' awareness of not being able to be with a loved-one or missing out and not sharing in their loved one's lives as they cannot attend a birthday party or important life event.

A community of people unified with Christ inaugurates church and celebrates their identity in Christ with baptism and the Lord's Supper. The Internet has a supportive role to play, but it remains necessary to physically engage in faith communities.

\section{Implications of a corporeal understanding}

The implications of Paul's corporeal understanding is that humans are constantly in a position where they need to orientate themselves towards God. In order for your body to be a space that is dominated by Christ and the fruits of the Spirit associated with Christ, it is necessary to continually align yourself with Christ. Aligning yourself with Christ from a Pauline perspective entails to continually determine what to live for and what to metaphorically die for.

43 From the discussion after I presented this paper "Digitalisation and the church" at Theologische Hochschule Ewersbach on 18 January 2019.

44 Jean-Francois Coget, Yutaka Yamauchi \& Michael Suman, "The Internet, Social networks and loneliness". IT \& Society 1, no.1 (2002): 196.

45 Pam Smith, "Meaningful communities, the growth of virtual churches". Transmission, Spring (2016): 12. 
Accordingly, it is vital for believers to be part of faith communities as the process of aligning with Christ is a never-ending action. Believers need encouragement to stay aligned in order to continually grow and engage in new possibilities. Online church services may have a positive effect, but to truly be part of a church community, congregants should partake in baptism and Eucharist. Churches that stream online should take great care in urging its online public to cultivate a healthy spirituality by participating in the body of Christ.

One of the problems of not participating in the body of Christ, is that online church viewing (as opposed to actual participation) runs the risk of creating a quasi-feel good Christianity. A person may view from the comfort behind a computer screen with the option to only listen to who/ what they would like to listen to and create friendship circles with people with similar ideologies. Unavoidably, a reductionist perspective of the reality of the world and its problems is created. With no one to disagree or enquire why certain beliefs are held, some perceived world problems might seem more pertinent than what they in fact are. Moreover, if a sermon is too challenging, it can easily be skipped or not listened to in full. Accordingly, a type of "Christianity" that only serves a person's own self-interest and needs precipitates.

Therefore, a church should consider its own online presence. It is necessary to seriously reflect on the church' understanding of their calling and purpose within their immediate context and also within the broader scope of South Africa. Such a process of discernment aids in clarifying what values and messages the church wants to promote. Vice versa, it enriches a congregations' understanding of the important role and function they play as community in their respective locations. Such an in-depth process might be time consuming, but also provides the possibility for other churches to become aware of what churches in their local vicinity are doing, which might aid in ecumenical projects and churches supporting one another. A broader perspective is essential to avoid contributing to a culture of church consumerism.

A populist approach may cause only more harm than good, adding to church consumerism. Churches should not shy away from preaching the gospel and staying true to Biblical exegesis. It is important to cultivate 
content that is not shallow and egoistic. An online presence requires a responsible theology and intentional preaching that invites its onlookers to participate physically.

The church should equip its members to live out their faith by also participating in outreaches and programs in their communities. Although there is an abundance of information, a particular theology and understanding of what a church wants to advocate does not only materialise in the form of Sunday sermons, but also in Bible studies and informational talks. These Bible studies and informational programmes can also be streamed for online participants. This improves communication and welcomes online participants to start fostering relationships with actual churchgoers. Connection becomes a reality, as a face and voice are added instead of a mere profile picture. Establishing a connection is of the utmost importance, as it may result in ascertaining why someone prefers to merely watch instead of physically attending. This could shed light on possible immobility problems or help to improve church engagement.

A virtual church where members create an avatar is not a church, as there is no connection with the real issues in the world to which God calls the church. Online churches should ensure that a chat function is maintained on their websites providing the possibility that a pastor or elder can make a house call if a person has a need for closer engagement or support. By preference, online communication related to church matters should be interactional. Churches with an online presence should keep their websites updated with opportunities to participate and engage with other believers.

What is more, churches should become aware of their responsibility in guiding members in an online Christian ethic. Online bullying and hate speech are often seen in the comment sections of webpages. The church can also play a necessary role in equipping its members with an understanding how to live out Christian values online, especially as virtual words have staying power. A creed or formal statement of a church's understanding of Christian values in a digital era may provide necessary guidelines. Such a creed could be enlightened in the liturgy of a service on occasion, being broadcast to online as well as physically present participants. It should also be available on the church website. 
Furthermore, a church should carefully consider how the baptism and Eucharist services are conducted. In a digital era where connection is craved, baptism and Eucharist provide an opportunity to strengthen Christian identity and community. Churchgoers should understand what these sacraments signify. Even if there is no baby or person to baptise, a pastor can use various moments during a sermon to underscore the significance of these sacraments during a prayer or taking a moment at the baptismal font. Rituals like these should be incorporated throughout the church year. An overflow of information requires churches to define and clarify their intent and purpose with the baptism and Eucharist.

\section{Conclusion}

The Internet provides a wonderful opportunity for cultivating connection. Much more research is necessary to track the impact of virtual identities and a constant online presence for the church as a collective community wanting to serve Christ. The Internet is a tool that the church should profit from and utilise in an effective manner. The fact that the Internet manages to help people in far off and remote places to connect, sets the table to initiate new ways for churches to share how God is moving them in their communities. However, churches need to be wary not to contribute to creating a church consumerism. Online churches can only play a supporting role, as the essential identity markers of church, such as baptism and the Eucharist, need to be expressed in a corporeal manner in a physical place.

\section{Bibliography}

Bauer, Walter, Danker, FW, Arndt, WF and FW Gingrich 2000. A GreekEnglish Lexicon of the New Testament and Other Early Christian Literature, 3d ed. Chicago: The University of Chicago Press.

Blass, F, A Debrunner and RW Funk 1961. A Greek Grammar of the New Testament and Other Early Christian Literature. Chicago, The University of Chicago Press. 
Breytenbach, C. “Taufe als räumliche Metapher in den Briefen des Paulus” in (Eds. C. Breytenbach \& F. Horn, Spatial Metaphors. Ancient Texts and Transformations. Berlin Studies of Ancient World 39(2016):127143.

Byrne, BSJ 1996. Romans. (Harrington, DJ (Ed.) Sacra Pagina Series Volume 6) Collegeville Minnesota, The Liturgical Press.

Calvary Fort Lauderdale "Calvary Fort Lauderdale.” [Online]. Available: https://www.calvaryftl.org/watch [Accessed: 21 January 2019].

Church of England, "Church of England.” [Online]. Available: https:// www.churchofengland.org/more/media-centre [Accessed: 19 January 2019].

Clivas, Claire "New Testament in a Digital Culture: A Biblaridion (Little Book) Lost in the Web?" Journal of Religion, Media \& Digital Culture (JRMDC) 3.(2014):20-38.

Coget, Jean-Francois, Yamauchi, Yutaka \& Suman, Michael, “The Internet, Social networks and loneliness," IT \& Society 1.I.1(2002):180-201.

Dreyer, W. "The real crisis of the church", HTS Teologiese Studies/ Theological Studies 71(3), 2015, Art. \#2822, 5 pages. http:// dx.doi. org/10.4102/hts. v71i3.2822.

EKD, "Kirche und digitalisierung." [Online]. Available: https://www.ekd. de/kirche-und-digitalisierung-33392.htm [Accessed: 19 January 2019].

E-Kerk, “E-Kerk,” Stephan Joubert. [Online]. Available: http://www.ekerk. org [Accessed: 19 January 2019].

Every day church, "Every day church." [Online]. Available: http:// everyday.org.uk/online [Accessed: 19 January 2019].

Fitzmyer, JA 1993. Romans. The Anchor Bible. New York: Doubleday.

Fung, RYK 1993. "Body of Christ” in (Eds. GF Hawthorne, R.P. Martin \& D.G. Reid), Dictionary of Paul and his letters. 76-82.

Harrisville, RA 1980. Romans. Augsburg Commentary on the New Testament. Minneapolis: Augsburg Publishing House. 
Hultgren, Arland. J 2011. Paul's letter to the Romans. Grand Rapids:

William B. Eerdmans Publishing Company.

Kruse, CG 2012. Paul's Letter to the Romans. Grand Rapids: William Eerdmans.

Nagy, Peter \& Koles, Bernadett. "The digital transformation of human identity: Towards a conceptual model of virtual identity in virtual worlds." The International Journal of Research into New Media Technologies 20.3(2014):276-292.

Moo, DJ 1996. The Epistle to the Romans. The New International Commentary on the New Testament. Grand Rapids: William B Eerdmans Publishing Company.

London Internet church, "London internet church.” [Online]. Available: http://londoninternetchurch.org.uk/mobile/ [Accessed: 19 January 2019].

Longenecker, RN 2016. The Epistle to the Romans - a Commentary in the Greek Text. The New International Greek Testament Commentary. Grand Rapids: WB Eerdmans Publishing.

Mounce, RH 1995. Romans. The New American Commentary - an Exegetical and Theological exposition of Holy Scripture NIV Text. Vol 27. USA: Broadman \& Holman Publishers.

Mullins, Todd J 2011. “Online Church: A Biblical community” (PhD diss. Liberal Theological Seminary.

Morris, L 1988. The Epistle to the Romans. Grand Rapids: William B Eerdmans Publishing Company.

New Life church. "New life church.” [Online]. Available: https://www. youtube.com/watch?v=Va5Pn_VHy2U [Accessed: 19 January 2019].

Punt, Jeremy. "Paul, body theology: Parameters of discussion" Neotestamentica 39.2(2005):359-388.

Saddleback. "Saddleback." [Online]. Available: https://saddleback.com/ watch [Accessed: 21 January 2019]. 
Schlier, H 1977. Der Römerbrief. Herdes Theologischer Kommentar Zum Neuen Testament Band VI. Freiburg: Herder.

Smit, Dirkie J. "Calvin on the sacraments and church unity." In die Skriflig 44.3(2010):247-269.

Smith, Pam 2016. "Meaningful communities, the growth of virtual churches." Transmission.

Vorster, Johannes N. "Spaces vying for power: The rhetoric of religion as a rhetoric of spatiality and the role of the public intellectual." Religion \& Theology 17(2010):329-357.

Wolter, M 2014. Der Brief an die Römer. Teilband 1: Röm 1-8. Evangelisch-Katholischer Kommentar zum Neuen Testament. Göttingen: Neukirchener Theologie Patmos Verlag.

Zeller, D 1985. Der Brief an die Römer. Regensburger Neues Testament. Regensburg: Verlag Friedrich Pustet Regensburg. 